\title{
Differences in cardiac chamber volumes during prone versus supine imaging
}

\author{
Hariharan Subramanian*, Vinod Kudagi, Lynette Duncanson, \\ Simcha Pollack and Nathaniel Reichek
}

Address: St.Francis Hospital, Roslyn, NY, USA

* Corresponding author

from 13th Annual SCMR Scientific Sessions

Phoenix, AZ, USA. $21-24$ January 2010

Published: 21 January 2010

Journal of Cardiovascular Magnetic Resonance 20 I0, I2(SuppI I):PI 28 doi:I0.I I86/I532-429X-I2-SI-PI 28

This abstract is available from: http://jcmr-online.com/content//2/SI/PI28

(c) 2010 Subramanian et al; licensee BioMed Central Ltd.

\section{Introduction}

Prone imaging may be an attractive strategy for improved visualization of right ventricular structure and function using CMR and is used extensively in SPECT myocardial perfusion imaging. Limited data are available on the effects of prone position on cardiac chamber sizes and function.

\section{Purpose}

We sought to determine the effects of prone positioning on right and left ventricular volumes and function using CMR.

\section{Methods}

11 subjects (27\% females), age 54.9+17.3, 10 without clinical heart disease and 1 with coronary artery disease and normal ventricular function were imaged in supine and prone position using retrospectively gated SSFP cine imaging in contiguous short axis planes covering both right(RV) and left (LV) ventricles. Left and right ventricular end diastolic(EDV) and end systolic volumes(ESV), stroke volume(SV), cardiac output(CO) and ejection fraction (EF) were derived for both positions by a single highly experienced image analyst using Medis QMass MR software version 6.2.3 and compared using paired t tests. Heart rate (HR) and blood pressure (BP) were also compared.

\section{Results}

(Table 1) Both LV and RV EDV and SV were reduced in prone versus supine position with a small increase in heart rate and no change in EF or BP. Thus $\mathrm{CO}$ was also significantly reduced. LV ESV did not change significantly but RV ESV was reduced in prone position.

\section{Conclusion}

In subjects with normal cardiac function, prone position appears to reduce biventricular preload with a resultant fall in stroke volumes and cardiac output. The mechanism of this effect and the response in subjects with cardiac dysfunction remains to be determined. Prone imaging may improve visualization of right ventricular free wall morphology but should not be used to evaluate right ventricular size. 
Table I: Prone and supine variables

\begin{tabular}{|c|c|c|c|c|}
\hline & & Prone & Supine & p-value \\
\hline \multirow[t]{5}{*}{ Left Ventricle } & $\mathrm{EDV}(\mathrm{ml})$ & $160.4+38.6$ & $17 \mid .5+39.2$ & 0.008 \\
\hline & $\mathrm{ESV}(\mathrm{ml})$ & $72.1+20.3$ & $75.7+20$ & 0.17 \\
\hline & $\mathrm{EF}(\%)$ & $55.3+6$ & $56.1+4.3$ & 0.42 \\
\hline & $\mathrm{SV}(\mathrm{ml})$ & $88.4+22.1$ & $95.7+21.2$ & 0.003 \\
\hline & $\mathrm{CO}(\mathrm{L} / \mathrm{min})$ & $5.9+1.3$ & $6.3+1.4$ & 0.016 \\
\hline \multirow[t]{5}{*}{ Right Ventricle } & $\mathrm{EDV}(\mathrm{ml})$ & $139.3+40.2$ & $160.2+40.2$ & 0.002 \\
\hline & $\mathrm{ESV}(\mathrm{ml})$ & $61.6+22.4$ & $69.1+19.6$ & 0.006 \\
\hline & $\mathrm{EF}(\%)$ & $56.7+7.5$ & $57.1+4.4$ & 0.77 \\
\hline & $\mathrm{SV}(\mathrm{ml})$ & $77.7+21.9$ & $91.1+22.8$ & 0.011 \\
\hline & $\mathrm{CO}(\mathrm{L} / \mathrm{min})$ & $5.2+1.3$ & $6.0+1.5$ & 0.012 \\
\hline Heart Rate & & $69+10$ & $65+9$ & 0.02 \\
\hline Systolic Blood pressure $(\mathrm{mmHg})$ & & $124.5+11.7$ & $125.4+13.9$ & 0.74 \\
\hline Diastolic Blood pressure(mmHg) & & $77+8.5$ & $75+9.6$ & 0.42 \\
\hline
\end{tabular}

Publish with Biomed Central and every scientist can read your work free of charge

"BioMed Central will be the most significant development for disseminating the results of biomedical research in our lifetime. "

Sir Paul Nurse, Cancer Research UK

Your research papers will be:

- available free of charge to the entire biomedical community

- peer reviewed and published immediately upon acceptance

- cited in PubMed and archived on PubMed Central

- yours - you keep the copyright

Submit your manuscript here:

http://www.biomedcentral.com/info/publishing_adv.asp
BioMedcentral 